\title{
Evolution in franchising: Trends and new perspectives
}

\author{
Luis Fernando Varotto ${ }^{\mathrm{A}}$ and Leonardo Aureliano-Silva ${ }^{1 \mathrm{~B}}$ \\ ${ }^{A}$ Universidade Nove de Julho - UNINOVE, São Paulo, SP, Brazil \\ ${ }^{B}$ Universidade Anhembi Morumbi - UAM, São Paulo, SP, Brazil
}

ARTICLE DETAILS
Article history:
Received: August 28, 2016
Accepted: October 11, 2017
Available online: November 12, 2017
Double Blind Review System
Scientific Editor
Ilan Avrichir

\section{Keywords:}

Franchising

Marketing

Theoretical approaches

\begin{abstract}
Franchising as a legal or marketing concept was not new. It arose as a structured business system in the US, around 1860's when The Singer Company established a network of resellers for sewing machines. Nowadays franchising is one of the fastest developing forms of business in the world. The evolution of theories that seek to explain franchise systems have been published in academic journals from time to time, but until now there was not a study that have established a social network analysis to quantify the degree of centrality and cohesion of the relationship between the main authors, journals, methods and theories in franchise. Therefore, the main purpose of this study is to extend the knowledge about franchising through an extensive research on its main theoretical perspectives into relevant international academic journals, showing the evolution of the field, highlighting the principal issues, authors and methods. Through a selection of 130 articles ranging from 1966 to 2015 the study investigates five relevant theories in franchising: (1) Resource Acquisition Theory, (2) Agency Theory, (3) Transaction Cost Analysis, (4) Signaling Theory, and (5) Property Rights Theory. A descriptive statistical analysis was done in order to identify the main authors and trends with the most used associated theories in franchise papers. The findings show agency theory and signaling theory, and resource scarcity theory as the main perspectives used in studies about franchising, but other perspectives have been increasing its presence, mainly the institutional theory and resource based-view perspective. The main dependent and independent variables cover a wide range of constructs, but ownership, performance, age, size, growth, geographical dispersion, and internationalization have been the most cited.
\end{abstract}

(C) 2017 Internext | ESPM. All rights reserved!

\section{INTRODUCTION}

Franchising as a legal or marketing concept was not new. It arose as a structured business system in the US, around 1860's when The Singer Company established a network of resellers for sewing machines (Antonowicz, 2011; Marques, 2006). In Brazil franchising surges in 1963 with the establishment of the Yazigi language schools network, and with the growth of malls contributing to the expansion of the system during de 80's and 90's (Marques, 2006).

Nowadays franchising is one of the fastest developing forms of business in the world. It can be conceptualized as a system of marketing goods and/or services and/or technology, which is based upon a close and ongoing collaboration between legally and financially separate and independent undertakings, that is, the franchisor and its individual franchisees, whereby the franchisor grants its individual franchisee the right, and imposes the obligation, to conduct a business in accordance with the franchisor's concept (Antonowicz, 2011).

Franchising also combines decentralized ownership of physical assets with centralized brand name ownership and provision of operational knowhow, and can be seen as facilitating growth by younger business chains, as it eases constraints on the supply of factors. Rapid initial growth may be 
necessary because promotion and advertising of a brand image is likely to be subject to both real and pecuniary economies of scale and almost all services and most physical outputs provided by the franchised business are difficult to protect from imitation, and this can involve expansion to preempt a rival's entry (Thompson, 1994).

Franchising is a rich field for studies not only in the Marketing arena, but also in another relevant areas such as economics, law, management, finance and entrepreneurship (Grewal, lyer, Javalgi, \& Radulovich, 2011), thanks to its varied possibilities of governance formats and studies about inter-organizational behaviors (Dant, Grünhagen, \& Windsperger, 2011). This plethora of perspectives has been inspired academic research in several areas - franchising as a vehicle for entering business ownership (entrepreneurship), as distribution channel (marketing), as a leading venue for understanding the structure of contracts (economics), as an important organizational form (strategic management) (J. G. Combs, Michael, \& Castrogiovanni, 2004) - mainly focusing in such facets as contractual arrangements, pricing strategies, franchised chain advertising, ownership patterns, territorial encroachment implications and internationalization (Chabowski, Hult, \& Mena, 2011).

These issues are investigated on the lenses of many perspectives, but five of them are the most prevalent (Dant et al., 2011) - resource acquisition theory (Oxenfeldt \& Kelly, 1969), agency theory (Fama \& Jensen, 1983a, 1983b), transaction cost analysis (WILLIAMSON, 1985), signaling Theory (Gallini \& Lutz, 1992; Gallini \& Wright, 1990) and property rights theory (Demsetz, 1966; Hart \& Moore, 1990; Maness, 1996) - although scholars have been using many other theoretical perspective approaches as well - stakeholder theory (D. Altinay \& Miles, 2006), tournament theory (James G. Combs, Ketchen Jr, \& Short, 2011; Gillis, McEwan, Crook, \& Michael, 2011), institutional theory (D. Altinay \& Miles, 2006), RBV (Barthélemy, 2008; J. G. Combs et al., 2004; Fladmoe-Lindquist, 1996), upper echelons theory (J. G. Combs et al., 2004), learning theory (J. G. Combs, Ketchen, Shook, \& Short, 2010); plural theory (Dant \& Kaufmann, 2003), risk-sharing theory (Hsu, Jang, \& Canter, 2010), social exchange theory (James G. Combs et al., 2011), resource dependence theory (Dant \& Gundlach, 1999), among other perspectives.
The following topics presents in detail these first five theories and their relevance to the franchise field. The main objective of this study is to extend the knowledge about franchising through an extensive research on its main theoretical perspectives into relevant international academic journals, showing the evolution of the field, highlighting the principal issues, authors and methods, identifying the most used theories and constructs in franchise publications along the last 30 years.

\section{THEORETICAL EVOLUTION IN FRANCHISING}

\subsection{Resource acquisition theory}

Oxenfeldt and Kelly published in 1969 an article entitled "Will successful franchise systems ultimately become wholly-owned chains?" which states franchising as part of a life cycle, where this system is adopted by firms to overcome scarce resources in their effort to growth, reverting in the future toward company ownership (Gillis et al., 2011). Oxenfeldt and Kelly were the first to formulate the termed resource scarcity view, which asserts that a nascent firm builds a brand in order to create economies of scale in advertising and purchasing (J. G. Combs et al., 2010; Oxenfeldt \& Kelly, 1969). New ventures need faster growth in comparison to established firms in order to compete successfully. Franchising is a method which permits new firms to rapidly penetrate the market and achieve access to key resources (Oxenfeldt \& Kelly, 1969).

Franchising, therefore, would be an alternative to overcome constraints to growth, as lack of trained managers and financial capital (Michael, 2003). According to the resource scarcity view, franchisees are seen as an inexpensive source of capital, enabling the franchisor to raise capital at a lower cost than other possible arrangements (Norton, 1988). Another prediction of the resource scarcity view is that franchisors will maintain the ownership over new outlets and will tend to repurchase the old ones in the extent to which economies of scale are achieved (J. G. Combs et al., 2010), in a phenomenon known as ownership redirection (Dant, Paswan, \& Kaufmann, 1996).

In this view, franchising would be advantageous to a franchisor mainly during the early years, when fundamental resources as financial capital, information regarding advantageous places for business, labor supply and managers to implement the system at dispersed locations would be necessary 
to implement and develop the business concept and achieve economies of scale. Along with the success of the chain other sources of financing will be available to franchisors, as well as their abilities and competencies in managerial labor training and site searching (Oxenfeldt \& Kelly, 1969; Dant, Kaufmann, \& Paswan, 1992; Michael, 2003). Once economies of scale have been reached and the need for rapid expansion reduces, new franchises should come to a halt, and the franchisor will tend to recover its most profitable franchised outlets (J. Combs \& Jr., 2003).

\subsection{Agency theory}

Agency theory along with resource scarcity theory try to explain why franchisors decide to franchise varying proportions of outlets (Castrogiovanni, Combs, \& Justis, 2006b). Differently the predictions of resource scarcity theory, franchisors do not repurchase all their franchised outlets when the system achieves maturity (Lafontaine \& Kaufmann, 1994), having important evidences of a stable balance between franchised and owned outlets over time, whose proportion may varies between different franchise chains (Tracey \& Jarvis, 2007). This aspect opens the way to other theoretical perspectives in franchising, such as agency theory.

Agency theory has its roots in the theory of the firm - designed by Coase in his seminal article entitled "The Nature of the Firm" published in 1937. In this work, he questions the role of the firm in the neoclassical perspective, arguing that the economic system is not controlled solely by the price mechanism. Under this view, there are at least two coordination mechanisms: under the market, pricing system indicates the best allocation of resources, and in the firm, under the principle of hierarchy, the Authority (entrepreneur) is responsible for the reallocation of resources. Agency theory is grounded on the principal-agent relationship, having the information transfer process, the information asymmetry problem and associated monitoring costs as its basis (Quinn \& Doherty, 2000).

Efficiency in delivering products demanded by customers - at lowest prices and covering costs - is a basic condition of surviving for organizations, and efficiency under the premises of agency theory is tied to the control of agency problems. Agency problems arise with the separation between ownership and control, that is, when decision process in the firm is under control of professional managers whose interests are different, and often divergent, from those of residual claimants - separation of ownership and residual risk bearing from control and decision functions. According agency view this problem could be managed through decision systems separating management (initiation and implementation) and control (ratification and monitoring) (Fama \& Jensen, 1983b). Face the divergent interests the principal is obliged to mobilize resources in order to ensure that the agent acts in the best interests of the principal. (Jensen \& Meckling, 1976). Principals can assure agents' cooperation mainly through two ways: monitoring or incentives for agents' behavior in accordance to the principals' interests (Castrogiovanni, Combs, \& Justis, 2006a; Eisenhardt, 1989).

Agency theory offers an alternative explanation in comparison the resource scarcity arguments for adoption of franchising with focus on the concept of efficiency (Rubin, 1978). According this view, franchisees, as owners of the businesses, have an incentive for enduring their best efforts into the activities, with less need of monitoring, therefore, reducing monitoring cost in franchising arrangements (James G. Combs, Ketchen, \& Hoover, 2004). One of the most studied factors which enable franchising to reduce monitoring costs is geographic dispersion (Castrogiovanni et al., 2006a), what is especially relevant when operations are in foreign countries (Fladmoe-Lindquist, 1996) and rural locations (Norton, 1988).

Although franchising is an alternative in reducing need of monitoring, this does not occur without potential costs to franchisors. Examples of potential costs are risk of franchisees free riding and transference of specific knowledge from franchisors to franchisees. Franchisees can be tempted to maximize their outlet's profits at the detriment of the franchisor's reputation by reducing the quality of the product or service offered, for example, what commits negatively the franchisor brand value (Brickley \& Dark, 1987; James G. Combs et al., 2004). Specific knowledge transference is also more complex in franchising arrangements than within firms because franchisees are not obliged sharing competitive practices or techniques developed or engaging in additional trainings, for example (James G. Combs et al., 2004). 


\subsection{Transaction-cost analysis}

Respecting the foundations of neoclassical economic behaviors, there is the emergence of contractual approaches of the firm, represented not only by the theory of agency, but also for the theory of transaction costs and by the theory of property rights. The theory of transaction costs or transaction-cost analysis (TCA), whose main exponent is Williamson, is a theory of firm governance with the transaction as unit of analysis, and transaction costs as opposed to production costs as focus of analysis. (Seggie, 2012).

Williamson (1975) develops the hypotheses that there are three forms of organizational governance market, hybrid and hierarchy - being each one supported by a different form of contract (Spinelli \& Birley, 1996). Market governance has the letter of the contract as the main source for solving conflicts, that is, the classical contract law, where formal terms overlaps less formal terms (Spinelli \& Birley, 1996). Hierarchy governance relies on the control over the use and disposition of assets, that is, ownership and integration in the same organization (Crocker \& Masten, 1996). Finally, hybrid governance is associated to parties that maintain autonomy but are interdependent, which is the form of governance in franchising contracts. The ideal form of governance will be that which permits the lowest transaction costs (Seggie, 2012).

TCA presuppose that parties engaged in a transaction, seek to maximize their returns, sometimes making use of opportunistic behavior (Williamson, 1979). Franchisors as well franchisees may behave opportunistically. Franchisors may overrun franchisees' markets, terminating contracts before the time assigned or misrepresenting costs, and franchisees may pursuit their private goals in detriment franchisor goals, misrepresent revenues, withhold royalties, and deviate from franchisor patterns, among other possibilities (Gassenheimer, Baucus, \& Baucus, 1996).

Other assumptions under TCA are bounded rationality and risk neutrality, besides four dimensions of transactions - asset specificity, behavioral uncertainty, environmental uncertainty, and transaction frequency (Seggie, 2012). Asset specificity is a central tenet in TCA, what links this theory directly to the central theme in franchising trademark, as an intangible asset (Spinelli \& Birley, 1996).
TCA under the perspective of franchising has at least two significant implications to the question of ownership redirection. One of them is related to the possibility of opportunistic behavior as a driver for ownership redirection hypothesis, and the other, based in the governance structures of specific transactions, related to the prediction of ownership of particular outlets around the combination of transaction and production costs (Dant et al., 1992).

\subsection{Property rights theory}

Theory of property rights considers the firm as a set of contracts that constitute a structure of property rights. Property rights involve the notion of control and ownership over the use of scarce resources, and the rights of sales and transferences related to this control. According to this theory approach, the assignment of property rights is important to achieve an efficient resource allocation (Demsetz, 1966). Any contract will be fully complete, since specification of all relevant circumstances in contracts would be too costly and difficult to establish, so every contract will remain some sort of not included residual rights.

Residual rights are responsible for the creation of large fraction of residual incomes, and under the property rights perspective they originate from assets not specified in the contract. Its main characteristics, and that which determines the ownership structure of the asset, is its intangibility (Hart \& Moore, 1990; Maness, 1996). Intangible assets are difficult to be codified and put in contracts, since they are tied to knowledge, skills and know-how. In the franchising system, franchisors as well as franchisees are holders of intangible assets.

Franchisors intangible assets are related to brand name and system specific know-how (Norton, 1988; Windsperger \& Dant, 2006), while franchisees intangible assets are related to the local know-how customer service, quality control, human resource management, product innovation (Sorenson \& Sorensen, 2001; Windsperger, 2001; Windsperger \& Dant, 2006).

The appropriation of the residual incomes generated from the residual rights will be directed to the party that owns the residual rights, whose asset is relevant for the success of the network (Windsperger, 2001), encouraging that party to invest in those intangibles assets. Therefore, if the franchisor system-specific expertise or brand name value is the most critical asset to generate the

Internext | São Paulo, v.12, n. 3, p. 31-42, sep./dec. 2017 
residual income, then the franchisor should have a larger part of ownership rights, reflected in high initial fees and royalties. Otherwise, if the franchisee local know-how is the most relevant asset to the success of the network, then the larger part of the ownership rights should be put upon him, reflected in low initial fees and royalties (Windsperger, 2001; Windsperger \& Dant, 2006).

\subsection{Signalling theory}

An alternative theoretical view to franchising is offered by signaling theory. While prior theories have focus into internal constraints facing firms, signaling theory focus on the externalities of market imperfections and knowledge asymmetries to explain franchising (Dant \& Kaufmann, 2003). In an environment where there is asymmetric information, firms may use several signs to provide information about themselves and their products, as pricing, advertising and warranties (Lafontaine, 1993). According this perspective, two primary forces drive such asymmetries: the nature of the subject under information search and the inability of individuals to assess informational cues. In franchising, due to the intangible nature of the assets (knowledge, brand, operational know-how), signaling is a relevant characteristic (Dant \& Kaufmann, 2003).

Gallini and Lutz (1992) describe franchising system evolution for observing dual distribution, with chains opening company-outlets until the point the firm is able to signaling the quality of their concepts, and, after that, establish a strategy tending toward franchising. This vision is opposite that of resource acquisition view, which defends franchising as a way to overcome scarcity of resources until the company grows and acquire enough resources for moving it toward the preferred strategy of company ownedoutlets (Dant \& Kaufmann, 2003).

Signaling theory also offer an explanation for franchisors' choices about royalties and fees. Royalties and fees, as well as company ownership can be used as a cue about the profitability of the business for potential franchisees interested to join the chain (Gallini \& Lutz, 1992). Finally, a relevant insight from the signaling literature in relation to franchising is that franchisors (at least those with a high-value trade name) who have not yet established their reputation can offer a contract that ties their revenues to the performance of the outlets, as a sign of confidence and quality (Lafontaine, 1993).

\subsection{Contemporary studies in franchising}

Despite different theories have been used to explain and analyzing franchising phenomenon since 1966, the main theories used since then continue to be the same (Forte \& Carvalho, 2013; Madanoglu, Lee, \& Castrogiovanni, 2013). However, mainly during the last 10 years, scholars begin to approach franchising growing with other than the traditional views. Institutional and/or resource base-view perspectives are two of these perspectives that arise with a nontraditional economic view of franchising, although other perspectives who works with social (L. Altinay, Brookes, Madanoglu, \& Aktas, 2014; Barthélemy, 2011) and individual aspects (Dada, 2013; Dant, Weaven, \& Baker, 2013) have increased their presence in the field. Probably, these two theories take into account the importance of to make partners whose help them legitimate their operation, for instance, in new countries (Marie Doherty, Chen, \& Alexander, 2014) and so, to have access to different resources (Smith \& Seawright, 2015).

Tab. 1

Theories, seminal works and respectively authors, and year of publication

\begin{tabular}{|c|c|c|c|}
\hline Theoretical Perspective & Seminal Work & Authors & Year \\
\hline Property rights theory & Some aspects of property rights. & Demsetz, $\mathrm{H}$. & 1966 \\
\hline Resource acquisition theory & Will successful franchise systems ultimately become wholly-owned chains? & Oxenfeldt, A.; Kelly, A. & 1969 \\
\hline Transaction-cost analysis & Transaction-cost economics: the governance of contractual relations. & Williamson, $\mathrm{O}$. & 1975 \\
\hline \multirow[t]{2}{*}{ Agency Theory } & Agency problems and residual claims & Fama, E.; Jensen, M. & 1983 \\
\hline & Separation of ownership and control. & Fama, E.; Jensen, M. & 1983 \\
\hline \multirow[t]{2}{*}{ Signalling theory } & Technology transfer under asymmetric information. & Gallini, N.; Wright, B. & 1990 \\
\hline & Dual distribution and royalty fees in franchising. & Gallini, N.; Lutz, N. & 1992 \\
\hline RBV & International franchising: capabilities and development & Fladmoe-Lindquist, $\mathrm{K}$ & 1996 \\
\hline Institutional theory & New Firm Survival: Institutional Explanations for New Franchisor Mortality & Shane, S.; Foo, M.-D. & 1999 \\
\hline
\end{tabular}

Source: Prepared by authors. 


\section{METHODS}

This work examines franchise systems under the lenses of five theories - resource constraints or resource acquisition theory, agency theory, transaction-cost analysis, property rights theory, and signaling theory, although there is a myriad of other perspectives in the literature.

Each of these theoretical perspectives has one or more seminal authors, whose works were used as a starting point for the literature search. The Table 1 shows the theories, seminal works and respectively authors, and year of publication: Web of Science database was used in order to seek for each of the seminal works related to these such five theories and later works published up to the year 2015, which used them as a reference. This research pointed to a huge amount of work and proportional to the importance of the work of each one of those authors. For each of the working groups associated with a particular author or authors of the five representatives' theoretical currents, a refinement was made to select only those works that possess references to franchising, franchise, franchisor and franchisee.

From this filter remained 182 references. As one of the goals of this work is to analyze the incidence of this theme in academic journals, chapters of books and articles not related to franchise were eliminated from the sample, which led to a final number of 130 articles in academic journals. From this selection, after reading the articles, it was registered the names of the periodicals, authors, year of publication, variables analyzed in the study, measures, methodology and theoretical orientation.

After tabulating the data, we applied descriptive statistics to identify the principal authors who have published, the most used methods, the journals that published more on this topic, the evolution of these publications a year, the theories used and the dependent and independent variables pointed out by the most relevant authors on the topic.

\section{ANALYSIS AND RESULTS}

From the 130 studies, the most part (32\%) used agency theory approaches, which is almost 3 times more than the second most used view - signaling theory (13\%). Table 2 shows the distribution of theoretical approaches along the 130 papers. (Some of the articles have more than one theoretical approach. In such cases, all the theories were considered to the analysis).

Tab. 2

Theoretical approaches

\begin{tabular}{lcc}
\hline Theory & No. Papers & $\%$ \\
\hline Agency Theory & 52 & 32 \\
Signalling Theory & 21 & 13 \\
Resource Scarcity Theory & 20 & 12 \\
Transaction Cost Analysis & 12 & 7 \\
Institutional Theory & 7 & 4 \\
Property Rights & 7 & 4 \\
RBV & 7 & 4 \\
Plural Theory & 6 & 4 \\
Entrepreneurial Orientation & 2 & 1 \\
Game Theory & 2 & 1 \\
Resource Dependence Theory & 2 & 1 \\
Risk-Sharing Theory & 2 & 1 \\
Social Exchange Theory & 2 & 1 \\
Stakeholder Theory & 2 & 1 \\
Tournament Theory & 2 & 1 \\
Other Theories & 18 & 11 \\
\hline
\end{tabular}

Source: Prepared by authors.

Although articles with the four main theories approaches sum more than $64 \%$ of the works, during the last 15 years, more and more theories have been used in order to analyze franchising phenomenon Table 3, showing the rising and the relevance of the field.

Tab. 3

Theoretical approach distribution over the years

\begin{tabular}{|c|c|c|}
\hline Period & Theories & $\mathrm{N}$ \\
\hline \multirow{2}{*}{ 1969-1989 } & Agency Theory & 2 \\
\hline & Resource Scarcity Theory & 1 \\
\hline \multirow{11}{*}{ 1990-1999 } & Agency Theory & 11 \\
\hline & Signalling Theory & 10 \\
\hline & Transaction Cost Analysis & 6 \\
\hline & Resource Scarcity Theory & 3 \\
\hline & Game Theory & 1 \\
\hline & General Theory of Franchising & 1 \\
\hline & Institutional Theory & 1 \\
\hline & Plural Theory & 1 \\
\hline & RBV & 1 \\
\hline & Resource Dependence Theory & 1 \\
\hline & Risk-Sharing Theory & 1 \\
\hline \multirow{12}{*}{ 2000-2009 } & Agency Theory & 27 \\
\hline & Resource Scarcity Theory & 13 \\
\hline & Signalling Theory & 6 \\
\hline & Plural Theory & 4 \\
\hline & Property Rights & 4 \\
\hline & Transaction Cost Analysis & 4 \\
\hline & RBV & 3 \\
\hline & Institutional Theory & 2 \\
\hline & Firm Theory & 1 \\
\hline & Game Theory & 1 \\
\hline & Stakeholder Theory & 1 \\
\hline & Upper Echellons Theory & 1 \\
\hline
\end{tabular}




\begin{tabular}{ll}
\hline Agency Theory & 12 \\
Signalling Theory & 5 \\
Institutional Theory & 4 \\
Property Rights & 3 \\
RBV & 3 \\
Resource Scarcity Theory & 3 \\
Entrepreneurial Orientation & 2 \\
Social Exchange Theory & 2 \\
Tournament Theory & 2 \\
Transaction Cost Analysis & 2 \\
Commitment Theory & 1 \\
Contingency Theory & 1 \\
Contingency Theory & 1 \\
Information Processing Theory & 1 \\
Networks & 1 \\
Organizational Ecology & 1 \\
Organizational Identity Theory & 1 \\
Plural Theory & 1 \\
Power-Dependence & 1 \\
Relational Governance & 1 \\
Relationship-Marketing & 1 \\
Resource Dependence Theory & 1 \\
Risk-Sharing Theory & 1 \\
Specific Knowledge Theory & 1 \\
Stakeholder Theory & 1 \\
Strategic Deviance Theory & 1 \\
Learning Theory & 1 \\
Momentum Individual Motivation & \\
International Business & \\
\hline
\end{tabular}

Source: Prepared by authors.

More recent works have introduced new perspectives to franchising, such as institutional theory (Barthélemy, 2011; J. G. Combs, Michael, \& Castrogiovanni, 2009; Zachary, McKenny, Short, Davis, \& Wu, 2011) and resource-based view (RBV)(James G. Combs et al., 2011; Polo-Redondo, Bordonaba-Juste, \& Palacios, 2011), stressing the relevance of others aspects to franchising beyond the traditional firm-specific economic factors. Such factors, associated to social forces, capabilities, and individual characteristics of franchisees and franchisors have achieved prominence in the field, and seems to present new avenues to franchising research.

Tab. 4

Main journals

\begin{tabular}{lc}
\hline Journals & No. of Articles \\
\hline Journal of Business Venturing & 11 \\
Journal of Small Business Management & 10 \\
Journal of Retailing & 9 \\
European Journal of Marketing & 7 \\
Service Industries Journal & 7 \\
Entrepreneurship Theory and Practice & 6 \\
Journal of Business Research & 6 \\
\hline
\end{tabular}

Source: Prepared by authors.
From 1966 to 2015, seminal works tied to the 5 theoretical perspectives examined under the field of franchising, generated:

- 130 articles, in 53 journals, by 155 authors, using 32 different theoretical perspectives;

- 51 different dependent variables, being the most used "ownership" (31 times), "performance" (18 times) and "royalty" /"fees" (7 times);

- 93 different independent variables, being the most used "age/experience" (32 times), "size" (21 times), "royalties/fees" (20 times), "growth" (16 times), and "internationalization" (13 times);

Along these 130 articles, the authors with more number of publications were J.G. Combs (10), R.P. Dant (9), S.C. Michael (9), F. Lafontaine (7), J. Windsperger (4), G.J. Castrogiovanni (6), P.J. Kaufmann (6), and D.J. Ketchen (5). Table 4 shows the main journals which have published works on franchising, and Table 5 show the publications in these journals over the years. Table 6 shows the most used methodological techniques (many articles have more than one methodological technique. In such cases, all the techniques were considered to the analysis).

Tab. 5

Publications in these journals over the years

\begin{tabular}{|c|c|c|}
\hline Period & Journals & $\mathrm{N}$ \\
\hline \multirow{4}{*}{$\begin{array}{c}1969 \\
- \\
1989\end{array}$} & Journal of Business & 1 \\
\hline & Journal of Financial Economics & 1 \\
\hline & Journal of Law \& Economics & 1 \\
\hline & Journal of Retailing & 1 \\
\hline \multirow{21}{*}{$\begin{array}{c}1990 \\
- \\
1999\end{array}$} & Journal of Business Venturing & 6 \\
\hline & Journal of Law Economics \& Organization & 2 \\
\hline & Journal of Political Economy & 2 \\
\hline & Journal of Retailing & 2 \\
\hline & Journal of Small Business Management & 2 \\
\hline & Management Science & 2 \\
\hline & Rand Journal of Economics & 2 \\
\hline & Academy of Management Journal & 1 \\
\hline & Applied Economics & 1 \\
\hline & International Journal of Industrial Organization & 1 \\
\hline & Journal of Business Research & 1 \\
\hline & Journal of Economic Behavior \& Organization & 1 \\
\hline & Journal of International Marketing & 1 \\
\hline & Journal of Law \& Economics & 1 \\
\hline & Journal of Management & 1 \\
\hline & Journal of Marketing Research & 1 \\
\hline & Journal of Public Policy \& Marketing & 1 \\
\hline & Journal of Regulatory Economics & 1 \\
\hline & Organization Science & 1 \\
\hline & Review of Industrial Organization & 1 \\
\hline & Strategic Management Journal & 1 \\
\hline
\end{tabular}

Internext | São Paulo, v.12, n. 3, p. 32-42, sep./dec. 2017 


\begin{tabular}{|c|c|c|}
\hline \multirow{34}{*}{$\begin{array}{c}2000 \\
- \\
2009\end{array}$} & Journal of Small Business Management & 5 \\
\hline & Service Industries Journal & 5 \\
\hline & Entrepreneurship Theory and Practice & 3 \\
\hline & Journal of Business Venturing & 3 \\
\hline & Journal of Economics \& Management Strategy & 3 \\
\hline & Journal of Management & 3 \\
\hline & Journal of Retailing & 3 \\
\hline & Strategic Management Journal & 3 \\
\hline & Entrepreneurship Theory and Practice & 3 \\
\hline & Journal of Business Research & 2 \\
\hline & Journal of Economic Behavior \& Organization & 2 \\
\hline & Accounting Review & 1 \\
\hline & Applied Economics & 1 \\
\hline & Cuadernos De Economia Y Direccion De La Empresa & 1 \\
\hline & Economic Institutions of Strategy & 1 \\
\hline & Economics Letters & 1 \\
\hline & European Journal of Marketing & 1 \\
\hline & European Management Journal & 1 \\
\hline & Health Policy and Planning & 1 \\
\hline & International Journal of Hospitality Management & 1 \\
\hline & International Journal of Service Industry Management & 1 \\
\hline & International Marketing Review & 1 \\
\hline & International Small Business Journal & 1 \\
\hline & Journal of Institutional and Theoretical Economics & 1 \\
\hline & Zeitschrift Fur Die Gesamte Staatswissenschaft & 1 \\
\hline & Journal of Law \& Economics & 1 \\
\hline & Journal of Law Economics \& Organization & 1 \\
\hline & Journal of Marketing & 1 \\
\hline & Journal of Real Estate Finance and Economics & 1 \\
\hline & Journal of Real Estate Research & 1 \\
\hline & Management Science & 1 \\
\hline & Rand Journal of Economics & 1 \\
\hline & Service Business & 1 \\
\hline & Cuadernos De Economia Y Direccion De La Empresa & 1 \\
\hline \multirow{20}{*}{$\begin{array}{c}2010 \\
- \\
2016\end{array}$} & European Journal of Marketing & 6 \\
\hline & Journal of Business Research & 3 \\
\hline & Journal of Retailing & 3 \\
\hline & Journal of Small Business Management & 3 \\
\hline & International Small Business Journal & 2 \\
\hline & Journal of Business Venturing & 2 \\
\hline & Service Industries Journal & 2 \\
\hline & International Entrepreneurship and Management J. & 1 \\
\hline & Japan and the World Economy & 1 \\
\hline & Journal of Hospitality \& Tourism Research & 1 \\
\hline & Journal of International Marketing & 1 \\
\hline & Journal of Management & 1 \\
\hline & Journal of Marketing Channels & 1 \\
\hline & Journal of Marketing Research & 1 \\
\hline & Journal of the Academy of Marketing Science & 1 \\
\hline & Journal of World Business & 1 \\
\hline & Management International Review & 1 \\
\hline & Service Business & 1 \\
\hline & Strategic Management Journal & 1 \\
\hline & Urban Affairs Review & 1 \\
\hline
\end{tabular}

Source: Prepared by authors.

\section{CONCLUSIONS}

As can be seen from the extensive bibliographic research, five major theoretical perspectives are highlighted in the last 50 years - the agency theory, resource-scarcity theory, signaling theory, transaction costs analysis, and property rights theory. Although these perspectives have been dominating the research in this area, other theoretical perspectives, some of them with a less economical connotation than those traditional, have been increasing its prominence.

Tab. 6

Most used methodological techniques

\begin{tabular}{lc}
\hline Methods & No. of Articles \\
\hline Regression analysis & 23 \\
Theoretical review & 22 \\
Logit regression analysis & 18 \\
Factor analysis & 12 \\
MANOVA/ ANOVA & 14 \\
OLS regression analysis & 8 \\
Case study & 7 \\
Structural equation modeling & 6 \\
Cluster analysis & 5 \\
Correlationship analysis & 5 \\
Econometric model & 4 \\
GLS estimation & 4 \\
Others & 39
\end{tabular}

Source: Prepared by authors.

The emergence of new theoretical perspectives also opens space for the study of new constructs, which ultimately further enrich the field of research in franchising.

Through the analysis is possible to realize a great degree of centrality of six periodicals - Journal of Business Venturing, Journal of Small Business Management, Journal of Retailing, European Journal of Marketing, Service Industries Journal, and Entrepreneurship Theory and Practice, that seem to be the main influential journals in the field of franchising. The degree of centrality also on methodological issues is quite relevant, prevailing quantitative studies with intensive use of several techniques of regression analysis, although theoretical reviews also occupy an important space in the research of the field.

This paper contributes to deepen the knowledge about the theory in franchising, as well as identifying trends and new perspectives of study. By showing the theoretical evolution of the field along the last 50 years, identifying the main theories, authors, periodicals, and methodologies contributes to show which are the main pillars where the theory in franchising was built, and shows the possibilities and perspectives of research in the area.

\section{REFERENCES}

- $\quad$ Altinay, D., \& Miles, S. (2006). International franchising decision-making: An application of stakeholder theory. The Service Industries Journal, 26, 421-436. 
- $\quad$ Altinay, L., Brookes, M., Madanoglu, M., \& Aktas, G. (2014). Franchisees' trust in and satisfaction with franchise partnerships. Journal of Business Research, $67,722-728$.

- Antonowicz, A. (2011). The dissemination of franchising all over the world: an attempt to access the scale of the phenomenon. Problems of Management in the 21st Century, 2, 8-18.

- Barthélemy, J. (2008). Opportunism, knowledge, and the performance of franchise chains. Strategic Management Journal, 29, 1451-1463.

- Barthélemy, J. (2011). Agency and institutional influences on franchising decisions. Journal of Business Venturing, 26, 93-103.

- Brickley, J. A., \& Dark, F. H. (1987). The choice of organizational form The case of franchising. Journal of Financial Economics, 18, 401-420.

- Castrogiovanni, G. J., Combs, J. G., \& Justis, R. T. (2006a). Resource Scarcity and Agency Theory Predictions Concerning the Continued Use of Franchising in Multi-outlet Networks. Journal of Small Business Management, 44, 27-44.

- Castrogiovanni, G. J., Combs, J. G., \& Justis, R. T. (2006b). Shifting Imperatives: An Integrative View of Resource Scarcity and Agency Reasons for Franchising. Entrepreneurship Theory and Practice, 30, 23-40.

- Chabowski, B. R., Hult, G. T. M., \& Mena, J. a. (2011). The Retailing Literature as a Basis for Franchising Research: Using Intellectual Structure to Advance Theory. Journal of Retailing, 87, 269-284.

- Coase, R. (1937). The nature of the firm. Economica, 386-405.

- Combs, J. G., Ketchen, D. J., \& Hoover, V. L. (2004). A strategic groups approach to the franchisingperformance relationship. Journal of Business Venturing, 19, 877-897.

- Combs, J. G., Ketchen, D. J., Shook, C. L., \& Short, J. C. (2010). Antecedents and Consequences of Franchising: Past Accomplishments and Future Challenges. Journal of Management, 37, 99-126.

- Combs, J. G., Ketchen Jr, D. J., \& Short, J. C. (2011). Franchising Research: Major Milestones, New Directions, and Its Future Within Entrepreneurship. Entrepreneurship Theory and Practice, 35, 413-425.

- Combs, J. G., Michael, S. C., \& Castrogiovanni, G. J. (2009). Institutional Influences on the Choice of Organizational Form: The Case of Franchising. Journal of Management, 35, 1268-1290.

- Combs, J. G., Michael, S., \& Castrogiovanni, G. (2004). Franchising: A Review and Avenues to Greater Theoretical Diversity. Journal of Management, 30, 907931.

- Combs, J., \& Jr., D. J. K. (2003). Why Do Firms Use Franchising as an Entrepreneurial Strategy?: A MetaAnalysis. Journal of Management, 29, 443-465.
- $\quad$ Crocker, K. J., \& Masten, S. E. (1996). Regulation and administered contracts revisited: Lessons from transaction-cost economics for public utility regulation. Journal of Regulatory Economics, 9, 5-39.

- Dada, O. (Lola). (2013). Entrepreneurial orientation and the franchise system: Organisational antecedents and performance outcomes. European Journal of Marketing, 47, 790-812.

- Dant, R. P., Grünhagen, M., \& Windsperger, J. (2011). Franchising Research Frontiers for the Twenty-First Century. Journal of Retailing, 87, 253-268.

- Dant, R. P., \& Gundlach, G. T. (1999). The challenge of autonomy and dependence in franchised channels of distribution. Journal of Business Venturing, 14, 35-67.

- Dant, R. P., \& Kaufmann, P. J. (2003). Structural and strategic dynamics in franchising. Journal of Retailing, $79,63-75$.

- $\quad$ Dant, R. P., Kaufmann, P. J., \& Paswan, A. K. (1992). Ownership redirection in franchised channels. Journal of Public Policy \& Marketing, 11, 33-44.

- $\quad$ Dant, R. P., Paswan, A. K., \& Kaufmann, P. J. (1996). What we know about ownership redirection in franchising: A meta-analysis. Journal of Retailing, 72, 429-444.

- $\quad$ Dant, R. P., Weaven, S. K., \& Baker, B. L. (2013). Influence of personality traits on perceived relationship quality within a franchisee-franchisor context. European Journal of Marketing, 47, 279-302.

- Demsetz, H. (1966). Some aspects of property rights. Journal of Law and Economics, 9, 61-70.

- Eisenhardt, K. (1989). Agency theory: An assessment and review. Academy of Management Review, 14, 5774.

- $\quad$ Fama, E., \& Jensen, M. (1983a). Agency problems and residual claims. JL \& Econ., 26, 327-349.

- Fama, E., \& Jensen, M. (1983b). Separation of ownership and control. JL \& Econ., 26, 301-325.

- Fladmoe-Lindquist, K. (1996). International franchising: Capabilities and development. Journal of Business Venturing, 11, 419-438.

- Gallini, N., \& Lutz, N. (1992). Dual distribution and royalty fees in franchising. Journal of Law, Economics, \& Organization, 8, 471-501.

- Gallini, N., \& Wright, B. (1990). Technology transfer under asymmetric information. The RAND Journal of Economics, 21, 147-160.

- Gassenheimer, J., Baucus, D., \& Baucus, M. (1996). Cooperative arrangements among entrepreneurs: an analysis of opportunism and communication in franchise structures. Journal of Business Research, 2963, 67-79.

- Gillis, W. E., McEwan, E., Crook, T. R., \& Michael, S. C. (2011). Using Tournaments to Reduce Agency 
Problems: The Case of Franchising. Entrepreneurship Theory and Practice, 35, 427-447.

- Grewal, D., Iyer, G. R., Javalgi, R. R. G., \& Radulovich, L. (2011). Franchise Partnership and International Expansion: A Conceptual Framework and Research Propositions. Entrepreneurship Theory and Practice, 35, 533-557.

- Hart, O., \& Moore, J. (1990). Property Rights and the Nature of the Firm. Journal of Political Economy, 98, 1119-1158.

- Hsu, L.-T., Jang, S. (Shawn), \& Canter, D. D. (2010). Factors Affecting Franchise Decisions in the Restaurant Industry. Journal of Hospitality \& Tourism Research, 34, 440-454.

- Jensen, M., \& Meckling, W. (1976). Theory of the firm: Managerial behavior, agency costs and ownership structure. Journal of Financial Economics, 3, 305-360.

- Lafontaine, F. (1993). Contractual arrangements as signaling devices: evidence from franchising. JL Econ. \& Org., 9, 256-289.

- Lafontaine, F., \& Kaufmann, P. J. P. (1994). The evolution of ownersip patterns in franchise systems. Journal of Retailing, 70, 97-113.

- Maness, R. (1996). Incomplete contracts and the choice between vertical integration and franchising. Journal of Economic Behavior \& Organization, 31, 101-115.

- Marie Doherty, A., Chen, X., \& Alexander, N. (2014). The franchise relationship in China: agency and institutional theory perspectives. European Journal of Marketing, 48, 1664-1689.

- Marques, D. S. P. (2006). Internacionalização de Franquias: um mapeamento sobre a presença de redes brasileiras no exterior. Dissertação (Mestrado) Faculdade de Economia, Administração E Contabilidade de Ribeirão Preto/USP, 144p.

- Michael, S. C. (2003). First mover advantage through franchising. Journal of Business Venturing, 18, 61-80.

- Norton, S. (1988). An empirical look at franchising as an organizational form. Journal of Business, 61, 197-218.

- Oxenfeldt, A., \& Kelly, A. (1969). Will successful franchise systems ultimately become wholly-owned chains. Journal of Retailing, 44, 69-83.
- Polo-Redondo, Y., Bordonaba-Juste, V., \& Palacios, L. L. (2011). Determinants of firm size in the franchise distribution system: Empirical evidence from the Spanish market. European Journal of Marketing, 45, 170-190.

- Quinn, B., \& Doherty, A. M. (2000). Power and control in international retail franchising - Evidence from theory and practice. International Marketing Review, 17, 354-372.

- Rubin, P. (1978). Theory of the Firm and the Structure of the Franchise Contract, The. JL \& Econ., 21, 223-233.

- Seggie, S. H. (2012). Transaction Cost Economics in International Marketing: A Review and Suggestions for the Future. Journal of International Marketing, 20, 4971.

- $\quad$ Sorenson, O., \& Sorensen, J. B. (2001). Finding the right mix: franchising, organizational learning, and chain performance. Strategic Management Journal, 22, 713724.

- Spinelli, S., \& Birley, S. (1996). Toward a theory of conflict in the franchise system. Journal of Business Venturing, 11, 329-342.

- Thompson, R. S. (1994). The franchise life cycle and the Penrose effect. Journal of Economic Behavior \& Organization, 24, 207-218.

- Tracey, P., \& Jarvis, O. (2007). Toward a theory of social venture franchising. Entrepreneurship Theory and Practice, 667-686.

- Williamson, O. (1979). Transaction-cost economics: the governance of contractual relations. Journal of Law and Economics, 22, 233-261.

- Windsperger, J. (2001). The fee structure in franchising: a property rights view. Economics Letters, 73, 219-226.

- Windsperger, J., \& Dant, R. P. (2006). Contractibility and ownership redirection in franchising: A property rights view. Journal of Retailing, 82, 259-272.

- Zachary, M. a., McKenny, A. F., Short, J. C., Davis, K. M., \& Wu, D. (2011). Franchise branding: an organizational identity perspective. Journal of the Academy of Marketing Science, 39, 629-645. 


\section{ABOUT THE AUTHORS}

- Luis Fernando Varotto. holds Master's and D.Sc. degree in Business Administration from Escola de Administração de Empresas de São Paulo -EAESP of Fundação Getúlio Vargas EAESP/FGV, São Paulo, $S P, B r a z i l$. Also is professor of the Postgraduate Program in Business Administration and Director of the Department of Management Sciences and Communication at University Nove de Julho. Email: varotto@uninove.br

- Leonardo Aureliano da Silva holds Master's and D.Sc. degree in Business Administration from the University Nove de Julho - UNINOVE, and a Post-doctorate in Business Administration with emphasis in International Management from Escola Superior de Propaganda e Marketing - PMDGI/ESPM, São Paulo, SP, Brazil. Also is Professor of the Professional Master's Program in Food and Beverage Management at Anhembi-Morumbi University and lecturer at ESPM. Email: leonardoaureliano@outlook.com 


\title{
Evolução em franquias: Tendências e novas perspectivas
}

\author{
Luis Fernando Varotto ${ }^{A}$ and Leonardo Aureliano-Silva ${ }^{B}$ \\ ${ }^{A}$ Universidade Nove de Julho - UNINOVE, São Paulo, SP, Brasil \\ ${ }^{B}$ Universidade Anhembi Morumbi - UAM, São Paulo, SP, Brasil
}

DETALHES DO ARTIGO
Histórico do artigo:
Recebido: 28 de agosto de 2016
Aceito: 11 de outubro de 2017
Disponível online: 12 novembro de 2017
Sistema de Revisão "Double Blind Review"
Editor científico:
Ilan Avrichir

\section{Palavras-chaves:}

Franchising

Marketing

Abordagens teóricas

\begin{abstract}
RESUMO
Franchising como um conceito legal ou de marketing não é recente. Ele surge como como um sistema de negócios estruturado nos EUA, por volta de 1860 quando a The Singer Company estabelece uma rede de revendas para máquinas de costura. Atualmente o franchising é uma das formas de negócio de mais rápido crescimento no mundo. A evolução das teorias que buscam explicar os sistemas de franquia tem sido publicadas em periódicos acadêmicos de tempos em tempos, mas até o momento não houve um estudo que tenha estabelecido uma análise de rede social para quantificar o grau de centralidade e de coesão do relacionamento entre os principais autores, periódicos, métodos e teorias em franquia. Por isso o principal propósito deste estudo é o de ampliar o conhecimento sobre franchising por meio de uma extensa pesquisa sobre suas principais perspectivas teóricas em periódicos acadêmicos internacionais relevantes, mostrando a evolução da área, ressaltando as suas principais questões, autores e métodos. Por meio de uma seleção de 130 artigos de 1966 a 2015, o estudo investiga cinco teorias relevantes em franquias: (1) Teoria da Aquisição de Recursos, (2) Teoria da Agência, (3) Analise dos Custos de Transação, (4) Teoria da Sinalização, e (5) Teoria dos Direitos de Propriedade. Uma análise estatística de característica descritiva foi realizada com o objetivo de identificar os principais autores e tendências com as teorias mais utilizadas em artigos sobre franquias. As descobertas mostram a Teoria da Agência, a Teoria da Sinalização e a Teoria da Aquisição de Recursos como as principais perspectivas utilizadas em estudos sobre franchising, mas outras perspectivas têm ampliado sua presença, principalmente a Teoria Institucional e a Perspectiva Baseada em Recursos. As principais variáveis dependentes e independentes cobrem uma ampla variedade de construtos, porém propriedade, desempenho, idade, tamanho, crescimento, dispersão geográfica e internacionalização tem sido as mais citadas.
\end{abstract}

(C) 2017 Internext | ESPM. Todos os direitos reservados!

To cite this article:

Varotto, L. F.; Aureliano-Silva, L. (2017). Evolution in franchising: trends and new perspectives Internext - Review of International Business, 12 (3), 31-42. DOI: http://dx.doi.org/10.18568/1980-4865.12331-42

To access this article: http://dx.doi.org/10.18568/1980-4865.12331-42 